\title{
先天性腓骨欠損症の観血的治療経験
}

\author{
鹿児島県立整肢園 \\ 竹之内 剛 - 肥 後勝 \\ 中 村 雅 洋 \\ 鹿児島大学整形外科
}

南周 作・小宮 節 郎

\section{Surgical Treatment for Congenital Fibular Deficiency}

\author{
Takeshi Takenouchi, Masaru Higo, and Masahiro Nakamura \\ Kagoshima Prefectural Crippled Children's Hospital, Kagoshima, Japan. \\ Syusaku Minami, and Setsuro Komiya \\ Department of Orthopaedic Surgery, Faculty of Medicine, \\ Kagoshima University, Kagoshima, Japan
}

\begin{abstract}
We reviewed the results of sugical treatment in three children with congenital deficiency of the fibula. The age at the time of surgery ranged from two to thirteen, and the follow-up period ranged from seven to ten years. They were each classified Type I A, Type I B, and Type II according to the classification of Achterman and Kalamchi. Two patients who had a stable hip and a plantigrade foot underwent langthening of the tibia or the femur and tibia, and one patient who had congenital anomalies of the foot underwent Syme amputation. All of them needed further corrective surgery. But at the final follow-up, all patients were satisfied with their daily life, and had no pain and limping. We suggest that estimation of foot deformity is essential for the surgical treatment of congenital deficiency of the fibula and various management methods should be designed for leg lengthening.
\end{abstract}

Key words : congenital fibular deficiency (先天性腓骨欠損症), fibular hypoplasia (腓骨形成不全), limb length discrepancy (下肢短縮), leg lengthening (下肢延長), Syme amputation (サ イム切断)

は じめに

先天性腓骨欠損症は，長管骨奇形の中で最も頻度が 高く, 下肢全体の腓骨列の形成不全のために下肢短縮, 外反足变形, 足根骨癒合症, 欠趾症などを合併しやす (1-4) とされ，その中で最も問題となるのは下肢短縮 である. 今回, 我々は 3 例の先天性腓骨欠損症の下肢 短縮に対し，2 例は下肢骨延長，1例はサイム切断之 下腿義足で治療し良好な結果を得たのでその治療経験 について報告する．

\section{対 象 症 例}

症例は, 男児 2 例, 女児 1 例であり, いずれも片側 罹患例であった。初回手術時年齢は 2 歳, 10 歳, 13 歳であった。最終手術から調查時までの術後経過期間 は, $7 \sim 10$ 年であった. Achterman and Kalamchi の腓骨欠損症の X 線写真分類 ${ }^{1)}$ では, 腓骨形成不全の Type I A が 1 例, Type I B が 1 例, 腓骨完全欠損の Type Iが 1 例であった。

術前臨床的には, 全例疼痛はなかったが, 跛行を呈 


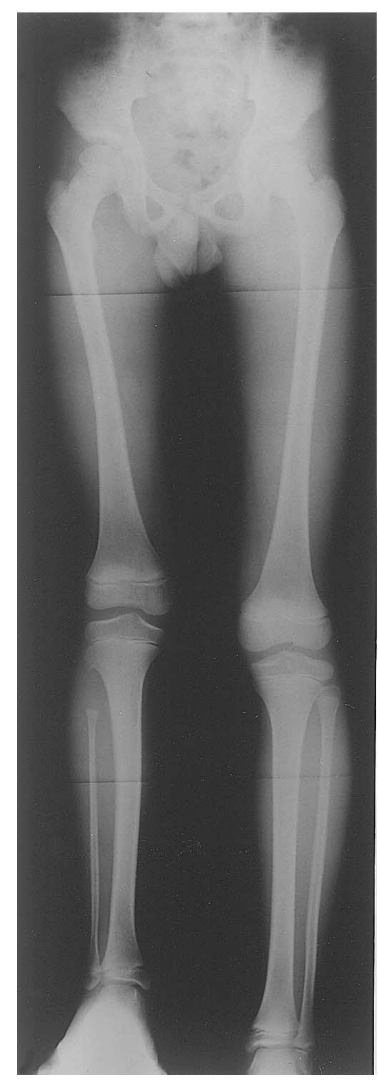

a)

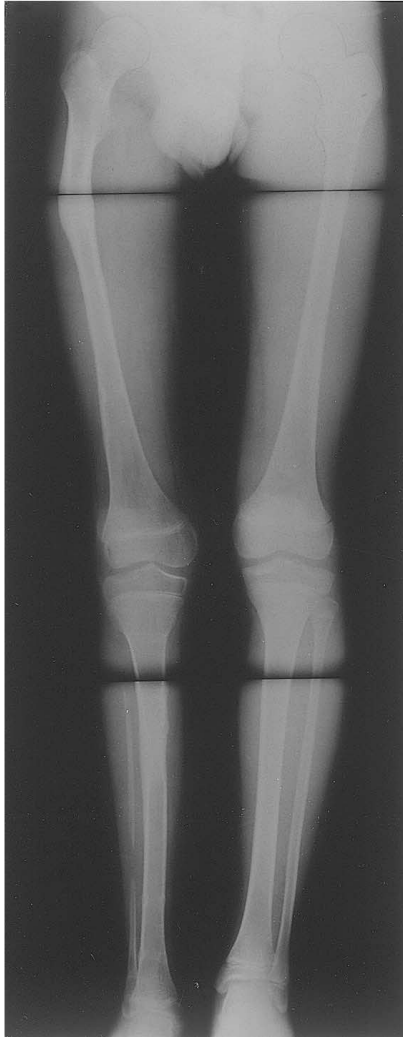

b)

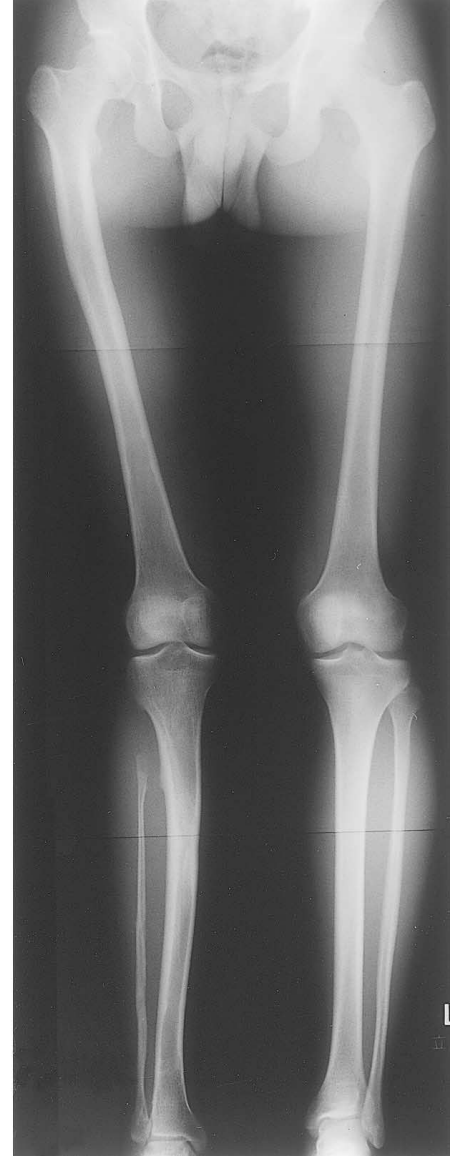

c)

図 1 症例 1.10 歳男児 Type I A.

a ） 10 歳時，骨延長前の両下肢 X線写真では，右下肢の $58 \mathrm{~mm}$ 短縮と腓骨形成不全を 認める。

b ） 12 歳時，右大腿骨之脛骨の同時骨延長 2 年後では，右下肢の $15 \mathrm{~mm}$ 過長と右大腿 骨近位の内反变形を認める。

c ） 18 歳の調査時, 内反变形の矯正，右下肢の $4 \mathrm{~mm}$ 過長と右膝の軽度外反を認める.

し，罹患側の下肢短縮，足関節の外反，側弯を認め,

Type II には，高度膝外反むあった。また全例に足部 変形があり, Type I A と I B の 2 例は外観的には plantigrade footであったが，X線上 Type I A には， 外側足趾列欠損之脛骨果部の形成不全を, Type I B には球状足関節，足根骨癒合を認めた。Type II は外 観的にもX線上も高度な奇形性变形を呈していた。術 直前の罹患肢の下肢短縮は大腿骨之脛骨だけでなく足 部あ短縮し， $41 \mathrm{~mm}, 58 \mathrm{~mm}, 76 \mathrm{~mm}$ であり,
Type I B と TypeIIでは脛骨と足部の短縮が顕著であっ た.

\section{治 療 方 法}

治療は，足部変形が軽度で高度下肢短縮のあった腓 骨形成不全の Type I A と I B の 2 例には Orthofix 創外固定器による仮骨延長を行った。 Type I A は, 10 歳時に骨成長を考慮して右下肢を $3 \mathrm{~cm}$ 過延長の 86

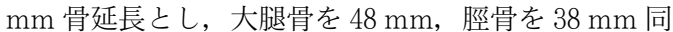


時に骨延長した。Type I B は， 13 歳時に脛骨を 45 $\mathrm{mm}$ 延長し, 18 歳時に同部位で $27 \mathrm{~mm}$ 骨延長し, 計 $82 \mathrm{~mm}$ 延長した。いずれも仮骨形成と骨癒合が不良 であり, healing indexは 68〜93 と大きな数值となっ た。腓骨完全欠損の Type II では 2 歳時に高度の奇形 性足部変形と膝関節外反に対しサイム切断と脛骨近位 での内反骨切り術を行い, 術後の下肢短縮は下腿義足 にて補正した.

\section{合併症および追加手術}

骨延長例の合併症として 1 日 $1 \mathrm{~mm}$ の延長速度で 骨延長したが，仮骨形成不良と骨癒合遷延を生じ，一 過性の膝関節拘縮と尖足をみた．Type I A の高度尖 足はアキレス腱延長により尖足を矯正し，大腿部近位 ピン刺入部の深部感染はピン抜去と抗生剂投与で治癒 をみたが，その 1 週後の骨延長部での骨折は鋼線牽引 により变形治癒した。 Type I B 屯創外固定器除去後 に骨延長部で骨折したが，再度創外固定器を装着し， 骨折の治癒機転と電気刺激療法により骨癒合を得た。 また骨延長した 2 例は脛骨遠位で足関節外反を生じた ので, 脛骨果上部内反骨切り術を追加し変形を矯正し た。 また Type I A の腓骨延長部の骨欠損は骨移植に より補口した。 サイム切断例では 7 歳時に脛骨内果部 の骨性突出部を骨切除した。

\section{結果}

最終調査時, サイム切断例は下腿義足にて生活して いたが，全例疼痛や跛行などの自覚症状はなく，日常 生活にも制限はなかった。骨延長した 2 例には軽度膝 関節外反があり，Type I B の球状足関節例には 5 度 尖足と背屈制限があった。調査時の下肢長差は，骨延 長した 2 例では Type I A が 4 mm 過長, Type I B が $9 \mathrm{~mm}$ 短縮となりほぼ等長化していたが，サイム切 断の Type II では $10 \mathrm{~cm}$ に増大していた.

\section{症 例 供 覧}

症例 1. 10 歳 男児 Type I A.

術前の下肢 $X$ 線写真で右下肢 $58 \mathrm{~mm}$ 短縮と腓骨形 成不全を認めた（図 1-a）。10 歳時に右大腿骨と脛骨 を同時骨延長して右下肢を $3 \mathrm{~cm}$ 過長の $86 \mathrm{~mm}$ 延長 した. 12 歳時のX線写真で右下肢の $15 \mathrm{~mm}$ 過長と右 大腿骨近位ピン刺入部の深部感染によるピン抜去後の 内反変形治癒骨折を認めた（図 1-b).18 歳の調査時,
臨床症状はなく，X線写真で内反变形矯正，下肢等長 化と右膝の軽度外反を認める（図 1-c).

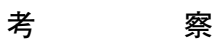

先天性腓骨欠損症は，高度の下肢短縮と罹患側下肢 や足部の種々の変形をきたす稀な疾患とされ，その治 療に際し最む問題となるのは下肢短縮である。以前は 義足あるいはサイム切断と義足による下肢長差補正に より治療されてきた。Choiら ${ }^{2)}$ は腓骨欠損症の 32 例 に対し平均 3.9 歳でサイム切断ないしボイド切断を行 い，平均 11.3 年の追跡調査では，28 例（88\%）は満 足のいく結果であったと報告している。しかし，最近 は骨延長により下肢等長化し，また随伴する種々の変 形屯矯正し足底接地可能な足部とすることにより良好 な下肢機能が獲得できるようになってきた

自験例の 3 例にも，全例下肢短縮があったが，足部 の高度の変形の有無によって治療方法を選択した．足 部の高度奇形性変形のあった 1 例は, サイム切断し下 腿義足で下肢長差を調整したが，合併症はなく，また 機能的にも良好な結果であった。自験例の他の 2 例は, 軽度の足部変形で足底接地できたので下肢延長したが， 先天性疾患のため仮骨形成が不良で骨癒合が遷延し， それに伴い種々の合併症を生じた. Miller ${ }^{3)}$ は先天 性腓骨欠損症の 11 例 12 下肢を Ilizarov 法で治療し， 良好な結果を得たが，11下肢に合併症がみられ，重 篤な合併症は骨癒合不全であったと報告している，従っ て，短期間に確実な骨癒合を得て合併症を少なくする 工夫が必要であると考える。良好な仮骨形成を得るた めには延長速度を $0.5 \mathrm{~mm}$ 程度の緩徐延長としたり, 短縮骨の 2 箇所での骨延長, $3 \mathrm{~cm}$ 程度の少量の多期 的な骨延長を行い良好な仮骨形成を図るべきである. また骨癒合を促進するためには電気刺激療法の併用む 有効であると考える.

\section{ま と め}

先天性腓骨欠損症の高度の下肢短縮に対し，2 例は 下肢延長により下肢等長化し，他の 1 例はサイム切断 と下腿義足により下肢長差を補正し，全例良好な結果 を得た。

\section{参 考 文 献}

1) Achterman, C. A., Kalamchi A. : Congential deficiency of the fibula. J. Bone Joint Surg., $61-\mathrm{B}$ : 
133-137, 1979.

2) Choi, I. H., Kumar, S. J., Bowen, J. R. : Amputati on and limb-lengthening for partial or total abscence of the fibula. J. Bone Joint Surg., 72-A : 1391-1399, 1990.

3) Miller, L. S., Bell, D. F. : Management of congenital fibular deficiency by Ilizarov technique. J. Pedatr. Orthop., 12 : 651-657, 1992.

4) Stevens, P. M., Arms, D. : Postaxial hypoplasia of the lower extremity. J. pedatr. Orthop., $20: 166-172$, 2000. 